\title{
Comparative effects of charred bamboo and its ash on the growth of E ntandrophragma angolense (welw.) C dc seedlings.
}

${ }^{1}$ A derounmu, A. F and ${ }^{* 2}$ Asinwa, I. O., ${ }^{1}$ O molewa, J. 0 and ${ }^{1}$ Ishola, J. 0

${ }^{I}$ Federal College of Forestry, Ibadan.

${ }^{2}$ Forestry Research Institute of Nigeria

*israelasinwa@gmail.com/ +2348035519395

Reserch Artide

\section{rese}

\begin{abstract}
ABST RACT
Entandrophragma anglenseis relatively slow growing species and its growth needs to be enhanced by soil nutrients amendment. Uniformed two weeks old seedlings of E. anglensewere transplanted into the polythene pots filled with $2 \mathrm{~kg}$ of degraded soil and mixed with different levels of biochar and ash produced from bamboo. A 2 x 7 factorial experiment was laid out in Completely Randomized D esign (CRD) with four replications to assess the effects of charred bamboo and its ash on the stem girth, leaf area, leaf production and shoot height of E. anglense The germination data were subjected to descriptive statistics and analysis of variance (ANOVA). There were significant differences $(\mathrm{p}<0.05)$ among the treatments in leaf area and shoot height while there were no significant differences ( $p>0.05)$ among the treatments in stem girth, leaf production and interactions among levels of biochar and ash. On stem girth, leaf production and shoot height, $\mathrm{T}_{6}(15 \mathrm{~g}$ of bio char $+15 \mathrm{~g}$ of ash + degraded soil) had the highest mean value of $4.27 \mathrm{~mm}, 4.59$ and $37.55 \mathrm{~cm}$ respectively while $\mathrm{T}_{2}$ ( $30 \mathrm{~g}$ of bio char + Og of ash + degraded soil) had the highest leaf area $\left(73.31 \mathrm{~cm}^{2}\right)$. The biochar and ash from bamboo had significant effects on the growth and development of E. anglenseseedlings on degraded soil.
\end{abstract}

Keywords: D egraded soil, Pyrolysis, Biochar, Ash, E. anglenæe

\section{Resume}

Entandrophragma angolense est une espèce à croissance relativement lente et sa croissance doit être renforcée par un amendement des éléments nutritifs du sol. D es plants en uniforme d'E. Angolense âgés de deux semaines ont été transplantés dans des pots en polyéthylène remplis de $2 \mathrm{~kg}$ de dégradé et mélangés avec différents niveaux de biochar et de cendre produite à partir de bambou. Une expérience factorielle $2 \times 1$ a été présentée dans une conception complètement aléatoire (CRD) avec quatre réplications pour évaluer les effets du bambou carbonisé et de ses cendres sur la circonférence de la tige, la surface foliaire, la production de feuilles et la hauteur de pousse d'Entandrophragma angolense. Les données de germination ont été soumises à des statistiques descriptives et à une analyse de variance (ANOVA). Il y avait une différence significative $(p<0,05)$ entre les traitements dans la surface foliaire et la hauteur des pousses alors qu'il n'y avait pas de différence significative ( $>$ > 0,05) entre les traitements dans la circonférence de la tige, la production de feuilles et les interactions entre les niveaux de biochar et de frêne. Sur la circonférence de la tige, la production de feuilles et la hauteur des pousses, T6 (15 g d'omble chevalier + $15 \mathrm{~g}$ de cendre + sol dégradé) avait la valeur moyenne la plus élevée de 4,27 mm, 4,59 et 37,55 cm respectivement tandis que T2 (30 g d'omble chevalier + $0 \mathrm{~g}$ de cendre + sol dégradé) avait la plus grande surface foliaire $(73,31 \mathrm{~cm} 2)$. Le biochar et les cendres de bambou ont eu des effets significatifs sur la croissance et le développement des semis d’E. Anglensesur un sol dégradé.

Mots clés: Sol dégradé, Pyrolyse, Biochar, Cendre, E. angdenße

Courtesy of Google Translator"

Received: 05/ 11/ 2020

Accepted: 20/ 12/ 2020

D OI: https/ / dx.doi.org/ 10.4314/ jcas.v16i3.1

(C) The Authors. This work is published under the Creative Commons Attribution 4.0 International Licence. 


\section{INTRODUCTION}

Plants generally need certain basic nutrients for optimum growth and development. There are seventeen (17) macro and micronutrients which plants need to survive. Three of these nutrients are taken from the air and from water: hydrogen, oxygen and carbon. A fertile soil must be able to contain the remaining fourteen (14) nutrients in the soil and if any one of the nutrients is deficient, it can slow plant growth or cause stunted growth (Plaster, 1996). The physico-chemical properties of the soil play a vital role in plant's ability to extract adequate moisture and nutrients from it; more so that the yield of crops is the function of soil potential to supply essential requirements (D iacono and Montemuro, 2010). There are four main primary factors that affect plant growth: light, water, temperature and nutrients. These factors affect the plant's growth hormones, making the plant to either grow more quickly or more slowly. Changes in any of the factors probably as a result of environmental degradation can negatively influence plant growth (Mader \& al, 2002). A rable and forest tree crops required soil with appropriate nutrients for optimum growth and development in spite of the fact that tree crops obtain needed nutrients beyond sub soil while arable crops are sustained with nutrients from topsoil (Mader \&al., 2002). Arable land can be severely degraded through erosion to the extent of exposing unproductive subsoil of soil profile (Bahr \& al., 2013). Soil degradation is due to a combination of loss of nutrients and organic matter, a decrease in the soil moisture holding capacity, changes in the soil structure and texture and reduction in soil depth (Bahr \& al, 2013). Several observations have been made that many indigenous timber and fruit tree species in the tropics such as Entandrophragma angdensegrow slowly despite the normal edaphic and environmental conditions (Oni and Ojo, 2002). The amendment of soil nutrients is therefore essential to instigate the rapid growth of some of these indigenous tree species especially $\mathrm{E}$. angolense

E.angolense is a large tropical forest tree that belongs to the family Meliaceae popularly called the mahogany tree (Hutchinson and Dalziel, 1958). Entandrophragma comprises about 10 species and is confined to tropical Africa. Other Common names include Mukusu (Uganda), Tiama (Ivory Coast), E dinam (Ghana), Kalungi (Zaire)(Njare al., 1995). In West Africa, E. anglenæeis most common in moist semi-deciduous forest, particularly in regions with an annual rainfall of $1600-1800 \mathrm{~mm}$ the tree reaches a height of $48.8 \mathrm{~m}$ and has a moderately straight bole (Chudnoff, 1984). It strongly prefers well-drained localities with good water-holding capacity (Njar \&al., 1995). The specieshas many medicinal uses like preparation for anti-malarial and anti-ulcer preparation. O ther uses like furniture, joinery, cabinetmaking, boat construction, decorative veneers and plywood cannot be underestimated (Njar et al., 1995). D espite the inestimable benefits of this tree, its natural stand has been threatened and there is no known plantation of the species. According to Spokas \& al., (2009) E.anglense seedling is relatively slow and its growth needs to be enhanced by ensuring availability of required soil nutrients with appropriate provision of light, water, temperature. Usually, the addition of organic matter such as compost and manure into soil can help retain nutrients and aid the soil's productivity. But these organic materials decompose very fast under the prevailing climatic conditions so that their benefits are often short lived (Bol $\notin$ al., 2000). Biochar has however been reported to last hundreds of years in the soil because of its aromatic structure which makes it resistant to microbial degradation (Chan \& al., 2007; Lehmann and Joseph, 2009). Biochar is a charcoal-like material that is produced from plant materials such as grass, agricultural and forest residues that are decomposed at high temperatures, often during renewable energy 
production. D uring the process, the physical and chemical properties of the plant material change into a highly porous, stable, carbon-rich material known as biochar. Recent research suggests it has the potential to be used as a soil conditioner and as a container substrate amendment in agriculture and horticulture, and it may improve several soil and substrate physical, chemical and biological properties (Yuan \& al., 2011). In order to reduce pressure on the forest, bamboo can be used as a substitute for timber in biochar production, as it will decrease deforestation. Besides, bamboo is highly sustainable as it can be regenerated within two to three years while timber could take longer than 25 years (FAO, 1997). Bamboo charcoal is one kind of manufactured biochar, it has highly micro-porous physical structure.(Cheng \& al., 2006). The porosity is about five times greater and the absorption efficiency ten times higher than that of wood charcoal. Bamboo charcoal may be an ideal amendment for nutrient conservation and heavy metal stabilization due to its excellent adsorption capability, the positive effect was related to the high adsorption capacity of biochar particles during composting (Zhao \& al., 2013). Recent research found that biochar could act as soil fertilizers or conditioners to increase crop yield and plant growth by supplying and retaining nutrients (Yao \& al.,2010). Cheng \& al., (2006) found that bamboo biochar is an effective fertilizer when incorporated with sludge composting thereby effectively reducing nitrogen loses in the soil.In view of the fact that biochar is considered much more effective than other organic matter in retaining and making nutrients available to seedlings at nursery stage (Spokaset al., 2009); this study therefore investigated the effect of bamboo biochar and its ash on the growth of E. anglense seedlings with a view of determining the best concentration level of biochars and ash for the optimum growth of $\mathrm{E}$. anglense seedlingsfor plantation establishment. MATERIALS AND METHODS

\section{Study Area}

The experiment was carried out at the Federal College of Forestry nursery, Jericho Hill, Ibadan. The College is located on the latitude $07^{\circ} 23^{\prime} 18^{\prime \prime} \mathrm{N}$ to $07^{\circ} 23^{\prime} 40^{\prime \prime} \mathrm{N}$ and longitude $03^{\circ} 36^{\prime} 20^{\prime \prime} \mathrm{E}$ to $030322^{\prime} 41^{\prime \prime} \mathrm{E}$. The climate of the study area is the West African monsoon with dry and wet seasons. The dry season is usually from November through March and is characterized by dry cold wind of harmattan. The wet season usually starts from A pril to October with occasional strong winds and thunderstorms. Mean annual rainfall is about $1548.9 \mathrm{~mm}$, falling within approximately 90 days (FRIN, 2015). The mean maximum temperature is $31.9^{\circ} \mathrm{C}$, minimum $24.2^{\circ} \mathrm{C}$ while the mean daily relative humidity is about 71.9\% (FRIN, 2015).

\section{Experimental Procedure}

Seeds of E. angdenæewere collected from a mother tree within the premises of the Forestry Research Institute of Nigeria. They were processed and soaked in water for eight (8) hours to facilitate germination before sown into a germination box filled with river sand in depth of about $5 \mathrm{~mm}$, and watering was done once a day. Degraded soil was collected from the College farm while it was analyzed to ascertain its initial physico-chemical status (Table 1). The bamboo culms used for the biochar and ash were gotten from the mango orchard, after the College farm Practical site, Federal College of Forestry, Ibadan. Bamboo culms werepyrolyzed to charcoal (biochar) under thermal condition as described by Odesola and 0 woseni,(2010).The biochar was then ground and passed through a 2-mmsieve. For the ash, dry bamboo was gathered and burnt right in the presence of excess air. The burning continued for about an hour until the bamboo was completely turned into a whitish-black substance known as the ash. The polythene pots with size $12 \times 9 \mathrm{~cm}$ were filled with $2 \mathrm{~kg}$ of degraded soil $\left(1 \times 10^{-6} \mathrm{~kg} /\right.$ ha) mixed with different levels of biochar and ash. 
After 2-3 weeks of germination, 42 healthy seedlings were pricked out of from the box and then transplanted into polythene pots filled with two kilograms (2 kg) of growing media and monitored for one week so as to stabilize and overcome pricking shock. The biochar and ash were applied two weeks (2 weeks) before transplanting into the degraded soil in powdered form at different grams. A $2 \times 7$ factorial experiment was laid out in Completely Randomized D esign (CRD) with four replications to assess the effects of charred Bamboo and its ash on the stem girth, leaf area, leaf production and shoot height of E. anglense The first factor was biochar and ash while the second factor was different levels of biochar and ash. The treatments combinations were: $\mathrm{T}_{1}=0 \mathrm{~g}$ of bio char $+0 \mathrm{~g}$ of ash $+2 \mathrm{~kg}$ of degraded soil (control), $\mathrm{T}_{2}$
$=30 \mathrm{~g}$ of bio char $+0 \mathrm{~g}$ of ash $+2 \mathrm{~kg}$ of degraded soil, $\mathrm{T}_{3}=0 \mathrm{~g}$ of bio char $+30 \mathrm{~g}$ of ash $+2 \mathrm{~kg}$ of degraded soil, $\mathrm{T}_{4}=25 \mathrm{~g}$ of bio char $+5 \mathrm{~g}$ of ash + $2 \mathrm{~kg}$ of degraded soil, $\mathrm{T}_{5}=20 \mathrm{~g}$ of bio char $+10 \mathrm{~g}$ of ash $+2 \mathrm{~kg}$ of degraded soil, $\mathrm{T}_{6}=15 \mathrm{~g}$ of bio char $+15 \mathrm{~g}$ of ash $+2 \mathrm{~kg}$ of degraded soil, $\mathrm{T}_{7}=$ $10 \mathrm{~g}$ of bio char $+20 \mathrm{~g}$ of ash $+2 \mathrm{~kg}$ of degraded soil, $\mathrm{T}_{8}=5 \mathrm{~g}$ of bio char $+25 \mathrm{~g}$ of ash $+2 \mathrm{~kg}$ of degraded soil. The collection of data commenced two (2) weeks after transplanting into polythene pot and carried out on a weekly basis for twelve (12) weeks. Data collected on stem girth (mm), shoot height $(\mathrm{cm})$, leaf area $\left(\mathrm{cm}^{2}\right)$ and numbers of leaves of $\mathrm{E}$. angolense seedlings were subjected to Analysis of Variance (ANOVA) using SPSS 2016 version and significant mean separated at 5\% level using Duncan Multiple Range Test (D MRT).

\section{RESULTS AND DISCUSSION}

\section{Table 1: Pre-cropping physical and chemical properties of degraded soil, Biochar and Ash}

$\begin{array}{llll}\text { Element(s) } & \text { D egraded soil } & \text { Biochar } & \text { Ash } \\ \mathrm{pH}\left(\mathrm{H}_{2} \mathrm{O}\right) & 6.72 & 8.25 & 7.49 \\ \mathrm{O} . \mathrm{C}\left(\mathrm{g} \mathrm{kg}^{-1}\right) & 1.67 & 39.57 & 45.29 \\ \text { Total Nitrogen }\left(\mathrm{g} \mathrm{kg}^{-1}\right) & 1.06 & 31.37 & 0.27 \\ \mathrm{Av} . \mathrm{P}\left(\mathrm{mg} \mathrm{kg}^{-1}\right) & 1.28 & 46.18 & 24.29 \\ \text { Exchangeable cations }\left(\mathrm{Cmolkg}^{-1}\right) & & & \\ \mathrm{Mg} & 0.83 & 2.56 & 2.27 \\ \mathrm{Na} & 0.27 & 0.17 & 0.15 \\ \mathrm{~K} & 0.38 & 24.73 & 22.53 \\ \mathrm{Ca} & 0.97 & 0 & 0 \\ \text { Extractable Micronutrients }\left(\mathrm{mg} \mathrm{kg}^{-1}\right) & & & \\ \mathrm{Mn} & 1.64 & 0 & 0 \\ \text { Fe } & 3.06 & 0 & 0 \\ \text { Zn } & 1.92 & 27.40 & 15.98 \\ \text { Cu } & 1.85 & 0 & 0 \\ \text { Particle size distribution }\left(\mathrm{g} \mathrm{kg}{ }^{-1}\right) & & & \\ \text { Sand } & 780 & & \\ \text { Silt } & 100 & & \\ \text { Clay } & 120 & & \\ \text { Textural class } & \text { Sandy Loam } & \end{array}$


The pre-cropping physical and chemical properties of soil, biochar and ash studied were presented in Table 1. The soil has a slightly acidic reaction (6.72) while the biochar (8.25) and ash (7.49) are slightly alkaline. The soil is deficient in total $\mathrm{N}$ $\left(1.06 \mathrm{~g} \mathrm{~kg}^{-1}\right)$, organic carbon $\left(1.67 \mathrm{~g} \mathrm{~kg}^{-1}\right)$ and available $\mathrm{P}\left(1.28 \mathrm{mg} \mathrm{kg}^{-1}\right)$ which is below the critical range (Adeoye and Agboola, 1985). The soil is moderate in potassium $\mathrm{k}\left(0.38 \mathrm{cmol} \mathrm{kg}^{-1}\right)$ however sufficient in exchangeable bases with sandy loam textural class. Biochar and ash had slightly alkaline reaction (8.25 and 7.49 respectively). Biochar had the highest amount of Nitrogen (31.37 $\mathrm{g} \mathrm{kg}^{-1}$ ), Phosphorus (46.18 mg $\left.\mathrm{kg}^{1}\right)$, Potassium (24.73 $\left.\mathrm{g} \mathrm{kg}^{1}\right)$ and Zinc (27.40 $\mathrm{mg} \mathrm{kg}$ ) while ash has the highest amount of carbon $\left(45.29 \mathrm{~g} \mathrm{~kg}^{-1}\right)$.

There were significant differences $(p<0.05)$ among the treatments in leaf area with highest separated mean by $\mathrm{T}_{2}\left(71.33 \pm 0.55 \mathrm{~cm}^{2}\right)$ while $\mathrm{T}_{8}$ $\left(51.10 \pm 0.61 \mathrm{~cm}^{2}\right)$ had the least mean (Table 2). Table 3 shows mean separation for leaf area as influenced by of biochar and ash on shoot height (cm) of E. anglense seedlings within period of study. The $\mathrm{T}_{6}(44.09 \pm 0.16 \mathrm{~cm})$ was significant different from other treatments most especially $\mathrm{T}_{8}(36.62 \pm 0.17 \mathrm{~cm})$. This is in line with findings of Yuan $\&$ al., (2011) that reported improved growth performance through biochar from crop residue with higher $\mathrm{pH}$. The acidic soil when amended with the biochar became less acidic. In the natural environment, the $\mathrm{pH}$ of the soil has an enormous influence on soil biogeochemical processes. Soil pH is, therefore, described as the "master soil variable" that influences myriads of soil biological, chemical, and physical properties and processes that affect plant growth and biomass yield (Minasny \&al., 2016; Brady and Weil, 1999). The highest shoot height and leaf area produced by the treatment with equal levels of biochar and ash on the degraded soil could be ascribed to higher $\mathrm{pH}$ from biochar and ash. Nitrogen (N), Potassium $(\mathrm{K})$, and Carbon contents play significant role in plant growth and productivity. The higher level of these nutrients in biochar and ash of bamboo and influence on the shoot development depicts their importance on plant growth. It could also be ascribed to the organic carbon that were added to the soil which probably increased the water holding capacity of the soil (Farrel and Jones, 2010; Beesley and Marmiroli, 2011).

Though, statistically there was no significant difference $(p>0.05)$ in stem girth and leaf production but from figure $1, \mathrm{~T}_{6}(15 \mathrm{~g}$ of bio char $+15 \mathrm{~g}$ of ash + degraded soil) had the average highest mean stem girth of $4.27 \mathrm{~mm}$, followed by $\mathrm{T}_{1}$ ( $0 \mathrm{~g}$ of bio char $+0 \mathrm{~g}$ of ash) with a mean value of $4.25 \mathrm{~mm}$ while $T_{7}(10 \mathrm{~g}$ of bio char $+20 \mathrm{~g}$ of ash + degraded soil) had the least mean value of $3.50 \mathrm{~mm}$.

\section{Table 2: Mean separation for leaf area as influenced by biochar and ash on Leaf area $\left(\mathrm{cm}^{2}\right)$ of $E$ ntandrophragma angolense seedlings within period of study}

$\begin{array}{ll}\text { Treatments } & \text { Mean } \\ \mathrm{T}_{1} & 59.92 \pm 0.41^{\mathrm{b}} \\ \mathrm{T}_{2} & 71.33 \pm 0.55^{\mathrm{a}} \\ \mathrm{T}_{3} & 54.83 \pm 0.31^{\mathrm{c}} \\ \mathrm{T}_{4} & 51.19 \pm 0.14^{\mathrm{d}} \\ \mathrm{T}_{5} & 61.16 \pm 0.22^{\mathrm{b}} \\ \mathrm{T}_{6} & 56.11 \pm 0.31^{\mathrm{c}} \\ \mathrm{T}_{7} & 55.89 \pm 0.52^{\mathrm{c}} \\ \mathrm{T}_{8} & 51.10 \pm 0.61^{\mathrm{d}}\end{array}$

Means with the same superscript are not significantly different $(p>0.05)$ 
Table 3: Mean separation for leaf area as influenced by iochar and ash on Shoot height $(\mathrm{cm})$ of Entandrophragma angdense seedlings within period of study

$\begin{array}{ll}\text { Treatments } & \text { Mean } \\ \mathrm{T}_{1} & 37.54 \pm 0.22^{\mathrm{b}} \\ \mathrm{T}_{2} & 39.17 \pm 0.12^{\mathrm{ab}} \\ \mathrm{T}_{3} & 41.63 \pm 0.11^{\mathrm{ab}} \\ \mathrm{T}_{4} & 40.89 \pm 0.25^{\mathrm{ab}} \\ \mathrm{T}_{5} & 43.46 \pm 0.32^{\mathrm{a}} \\ \mathrm{T}_{6} & 44.09 \pm 0.16^{\mathrm{a}} \\ \mathrm{T}_{7} & 41.25 \pm 0.23^{\mathrm{ab}} \\ \mathrm{T}_{8} & 36.62 \pm 0.17^{\mathrm{c}}\end{array}$

Means with the same superscript are not significantly different $(p>0.05)$

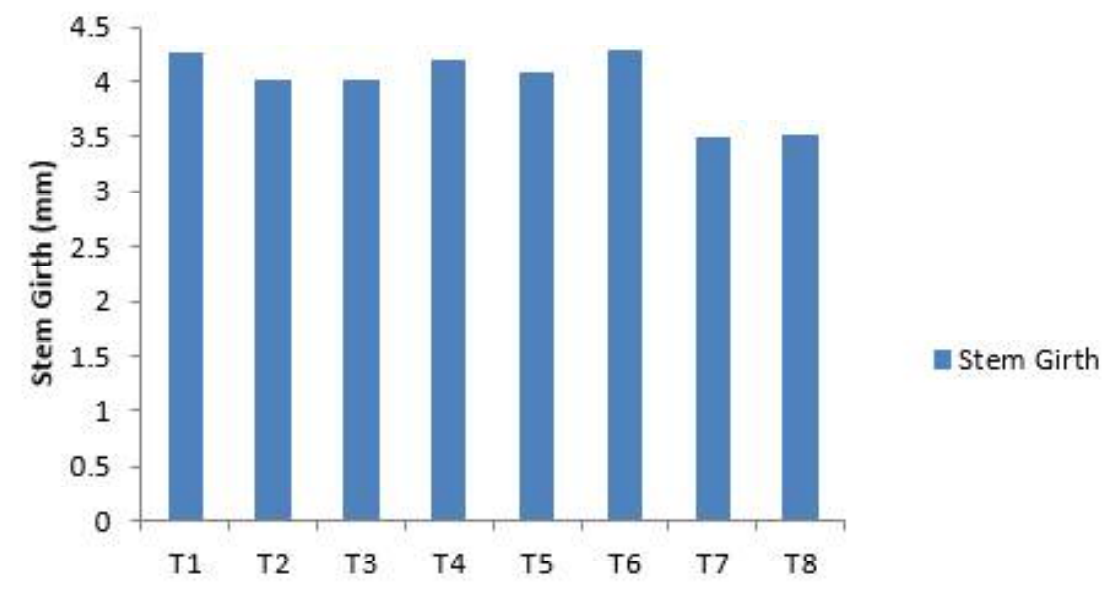

Treatments

Figure 1: Effect of biochar and ash on stem girth of $E$.angolenseseedlings.

Figure 2 shows that $\mathrm{T}_{2}$ ( $30 \mathrm{~g}$ of bio char $+0 \mathrm{~g}$ of ash + degraded soil) had the highest leaf area with a mean value of $73.31 \mathrm{~cm}^{2}$, followed by $\mathrm{T}_{5}(20 \mathrm{~g}$ of bio char $+10 \mathrm{~g}$ of ash + degraded soil) with a mean value of $61.18 \mathrm{~cm}^{2}$ while $\mathrm{T}_{8}(5 \mathrm{~g}$ of bio char $+25 \mathrm{~g}$ of ash + degraded soil) had the least mean value of $51.11 \mathrm{~cm}^{2}$. This corroborated the findings of Lehmann, (2007) who reported on improvement of acidic soil using biochar and inorganic fertilizer (N:P:K 15:15:15) as treatments. It was found that independently, biochar can increase soil fertility of acidic soils (low pH soils), increase agricultural productivity and provide protection against some foliar and soil-borne diseases. The biochar is composed of many major and minor elements that trees need for growth (Lehmann, 2007). Since most of these elements are extracted from the soil and atmosphere during the tree's growth, they are common in our environment and are also essential in production of crops and forages. The biochar and ash of the carbonized bamboo has higher quantity of $\mathrm{P}$ and $\mathrm{K}$ which are considered as nutrients that all plants needs in fairly large quantities (relative to their size) for healthy growth. In addition to these macro-nutrients, wood ash is a good source of many micronutrients needed in trace amounts for adequate plant growth. This result confirms the assertion that all plants require adequate supply of essential nutrients to grow well in degraded soil ( Adelani \& al, 2020; Arif \& al, 2012; Fagbenro \& al, 2012; Bar \& al., 2013). Other macronutrients such as Nitrogen, Calcium, Sulphur (S), and Magnesium promote G reen leaves, vegetative growth, and sugar formations are being sustained by the presence of biochar (Yao \& al.,2010). Essential elements from the soil are absorbed by plants through their roots and from the air (mainly consisting of 
nitrogen and oxygen) through their leaves. Nutrient uptake in the soil is achieved by cation exchange through diffusion process, wherein root hairs pump hydrogen ions $\left(\mathrm{H}^{+}\right)$into the soil through proton pumps. All which amount physiological development of the plants. It was found from a study that biochar could act as soil fertilizers or conditioners to increase crop yield and plant growth by supplying and retaining nutrients (Lehmann, 2007; Bar $\notin a \mathrm{al} ., 2013)$. Cheng $\notin a l .,(2006)$ found that bamboo biochar is an effective fertilizer when incorporated with sludge composting thereby effectively reducing nitrogen loses in the soil which eventually enhances plant growth.

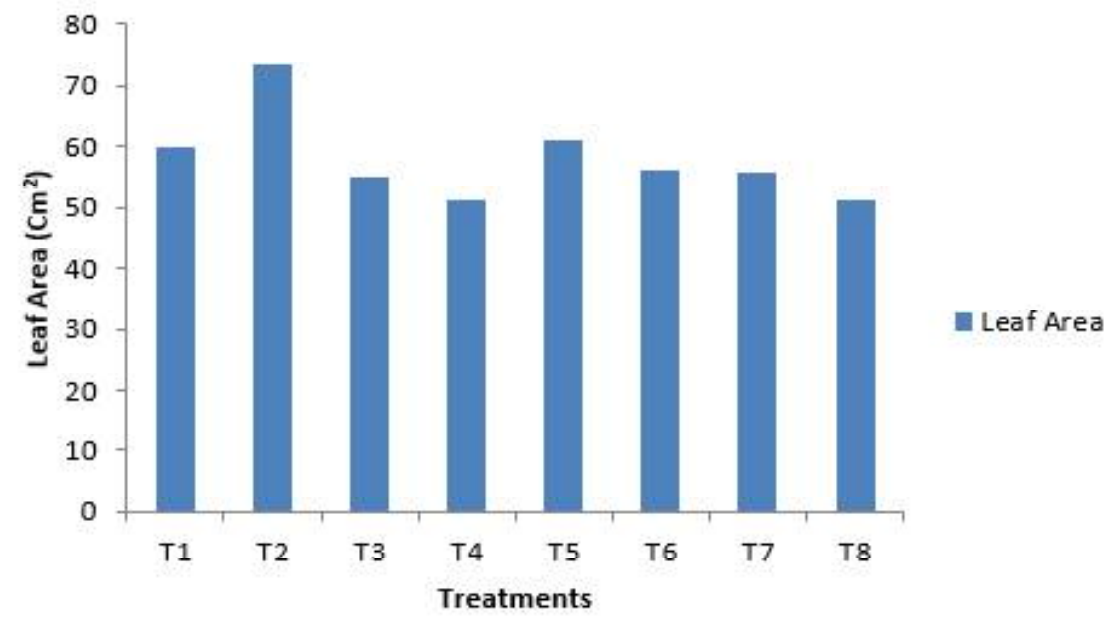

Figure 2: Effect of biochar and ash on the leaf area $\left(\mathrm{cm}^{2}\right)$ of $E$. angolense seedlings.

As shown in figure $3, \mathrm{~T}_{6}$ had the highest mean leaf production of 4.59 , followed by $\mathrm{T}_{8}$ with a mean value of 4.48 while $\mathrm{T}_{1}$ (control) had the least mean value of 3.97 . This result was in accordance with the findings of G laser $\& \mathrm{al}$., (2002) who carried out a research on the amelioration of physical and chemical properties of highly weathered tropical soil using biochar and ash as treatments that Biochar and ash act as soil conditioner thereby enhancing plant growth most especially on leaf production while producing other services such as improving soil physical and biological properties. Being one of the important parts of the plant, leaves have several essential functions such as photosynthesis, transpiration, guttation and storage, among others. Meanwhile, for plant foliage to flourish, optimum soil nutrients are required which can be sustained by biochar. According to Tryon, (1999) a gradual increase in ash concentration in the soil at different proportion increase the porosity, water holding capacity, ${ }_{\mathrm{P}} \mathrm{H}$, conductivity, cation exchange capacity (C.E.C), sulphate, carbonate, bicarbonate, chloride and other essential soil minerals.

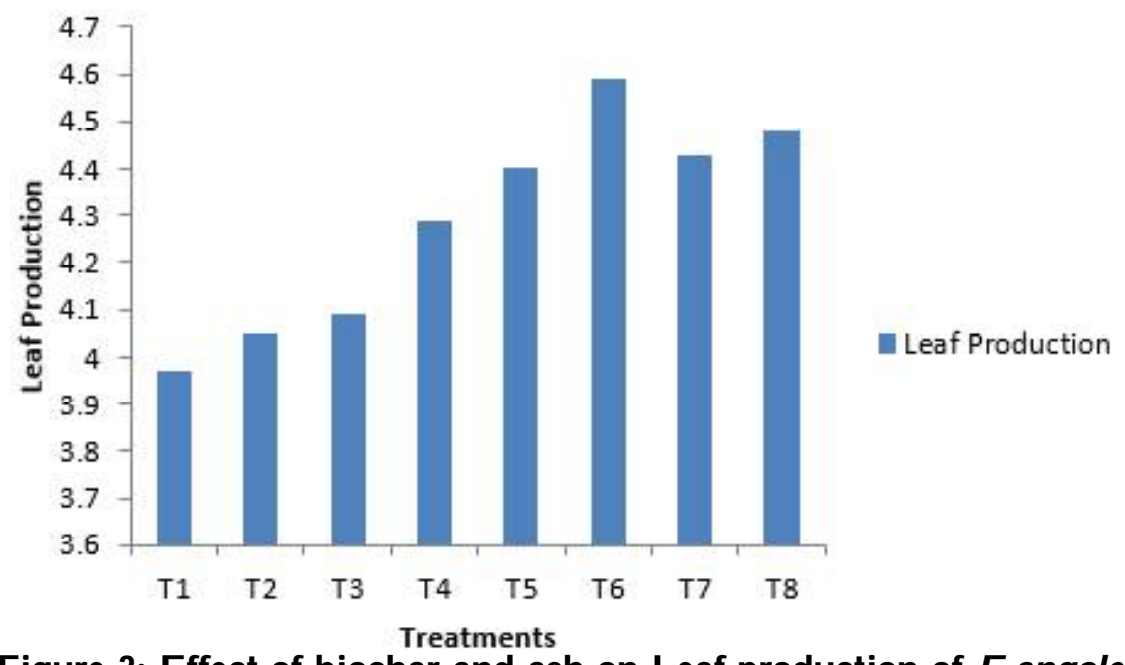

Figure 3: Effect of biochar and ash on Leaf production of $E$.angolenseseedlings. 
Figure 4 show that $\mathrm{T}_{6}$ had the highest shoot height with a mean value of $44.08 \mathrm{~cm}$, followed by $\mathrm{T}_{5}$ with a mean value of $43.45 \mathrm{~cm}$ while $\mathrm{T}_{1}$ had the least $(37.55 \mathrm{~cm})$. This is in accordancewith Lehmann and Joseph (2009) who carried out a study on amendment of degraded soil management using biochar. It was found that the application of biochar and ash can increase yields on formerly degraded soils by as much as 300 percent or more.

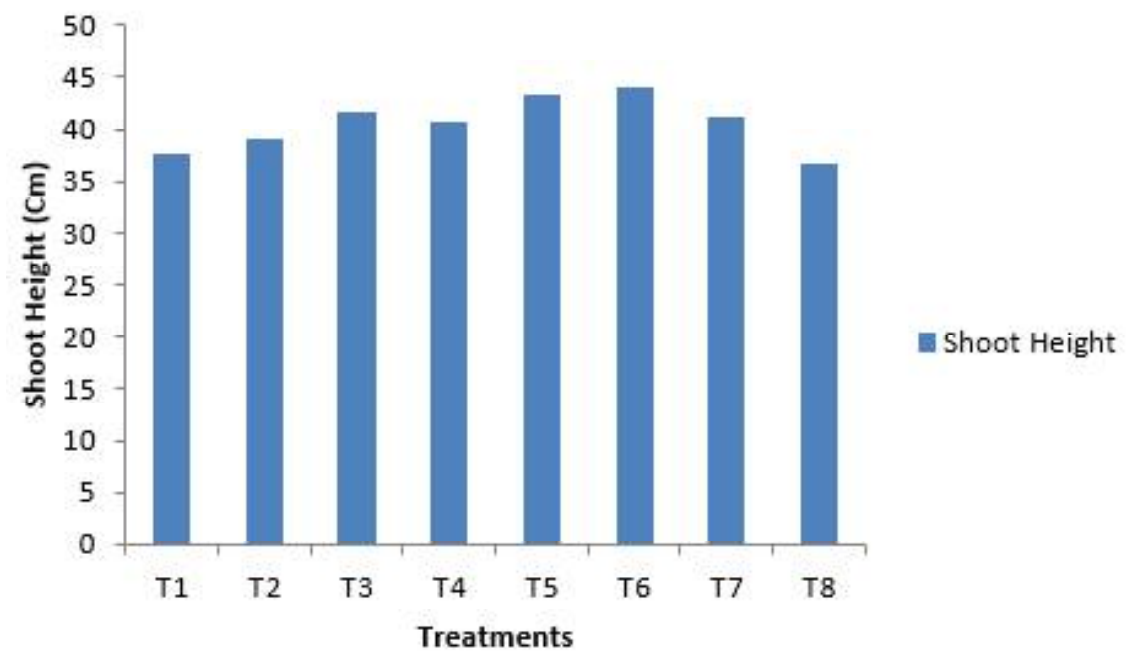

Figure 4:E ffect of biochar and ash on Shoot height of $E$.angolenseseedlings

\section{CONCLUSION AND}

\section{RECOMMEN DATION}

Biochar and ash had influence on the growth and development of E. anglense seedlings in the nursery. The biochar and ash from bamboo had significant effects on the growth and development of E. anglenseseedlings on degraded soil in terms of its height and leaf production. Different levels of biochar and ash mixed with degraded soil had varying influences on the species growth parameters. Therefore, it could be inferred that biochar and ash application in equal proportion is effective to be used on degraded land towards improvement of the soil nutrient status and it can also be used as alternative to inorganic fertilizers for seedlings production.

\section{REFERENCES}

Adelani, D.O., O ni, B.O and Ariyo, O.C. (2020). Effect of leaflitters of nitrogen fixing acacia trees on the growth of A frican star apple (Chrysqphylum albidumG.D on): A step towards enhancing the growth of an endangered species. Journal of Research in Forestry, Wildlife and Environment, 12(2):130-140.
Adeoye, G. O., and Agboola, A. A., (1985). Critical level for soil $\mathrm{pH}$, available $\mathrm{P}, \mathrm{k}, \mathrm{Zn}$ and maize ear leaf content for $\mathrm{P}, \mathrm{Cu}$ and $\mathrm{Mn}$ in sedimentary soils of Southwestern Nigeria.6: 65 - 71 .

Arif, M., Alli, A., Umair, M., Munsi, F., Alli, L $\backslash$ K., Inumullah, saleem, $M$ and Gohar, A. (2012): Effect of

Biochar, Farm yard Manure and Mineral Nitrogen and in Combination on Yield and Components of Maize. Sarhad Journal of Agialture Vol. 28, No 2; 191-195

Bar, E., Hamer, U., Zaragocin, D. C and Makeschin, F (2013): Different Fertilizer Types Affected Nitrogen and Carbon Cycling in Eroded and Colluvial Soils of Southern Ecuador. Agricultural Sciences. Vol. 4, No 12 A: 19-32 http:// dx.doi.org10.4236. Accessed 25/ 04/ 2020

Beesley, I and Marmiroli, M (2011): The Immobilization and Retention of Soluble Arsenic, Cadmium and Zinc by Biochar. Envirammental Pdlution 159 (2): 474-480 
Bol, R.A., Fredrich, C., O stle, N. (2000): Tracing Dung-derived Carbon in Temperate G rassland using 13Natural Abundance Measurement. Sail and Biochemistry 32: 1337-1343.

Brady, N. C. and Weil,R. R (1999):TheNatureand Propety of Sails Prentice Hall, Upper Saddle Hall, NJ, USA, 1999.

Chan, K. Y., Z wieten, L. V., Meszaros, I., D ownie, A., and Joseph, S., (2007):Agronomic values of greenwaste biochar as a soil amendment. Australian J. Sail Res 45, 629-634.

Cheng, C.H.; Lehmann, J.; Thies, J.E.; Burton, S.D.; and Engelhard, M.H. (2006): Oxidation of black carbon by biotic and abiotic processes. Org Geochem, 37, 1477-1480.

Chudnoff, Martin. (1984): Tropical Timbers of the World. USDA Forest Service. Ag. Handbook No. 607.

Diacono, M and Montemuro, F (2010): Long term Effects of O rganic Amendments on Soil Fertility. A ReienAgronamy for Sustainable Devdqpment, 30: 401-422

Arbestain, F. X.,Virgel, M. C., Blanco, S., Arostegui, F., Maciá-Agulló, J.A. and Macías, F (2010): Simulated geochemical weathering of a mineral ash-rich biochar in a modified soxhlet reactor. Chemosphere, 80, 724-732.

FAO (1997): Provisional outlook for global forest products consumption, production and trade. Forestry D epartment, Policy and Planning Division, FAO, Rome (2):7-14.

Fagbenro, J. A., salami, B. T., O shunsanya, S.O and Aduayi, E. A (2012): The Potential and promise for Sustainble Soil Productivity and Crop production, Eniron tropical 8: 89-110
Farell. M and Jone, D. L. (2010): Use of Composts in the Remediation of Heavy metal Contaminated Soil. O urnal of Hazardous Material, 175: 575-582. http:/ / dx.doi.org10.4236/j.hazmat. 28/ 4/ 2020

Forestry Research Institute of Nigeria (2015): Annual Report of Forestry Research Institute of Nigeria.

Glaser, B., Lehmann, J. E., and Zech, W. (2002): "Ameliorating physical and chemical properties of highly weathered soils in the tropics with charcoal - a review". Biology and Fertility of Soils (4) pp. 35.

Hutchinson, J. and Dalziel, J.M. (revised by Keay, R.W.J.) (1958): Flora of West Trqpical Africa, vd. 1, part2 2ndeeition Crown Agents. London. Pp. 432510

Lehmann, J., Joseph, S., (2009): Biochar for Environmental Management: Sience andTedhndogy. Earthscan, London and Sterling, VA. Pp 1- 12

Minasny, B., Hong, S. Y and Hartemink, A. E. (2016): Y. H. Kim, and S. S. Kang, "Soil pH increase under paddy in South Korea between 2000 and 2012," Agialture Ecosstens \& Enirament, vol. 221, pp. 205-213, 2016. View at: $\underline{\text { Publisher }}$ Site | Google Scholar

Njar V.C.O, Adesanwo J.K, and Yinusa R (1995). Methyl angolensate: the antiulcer agent of the stem bark of Entandrophragma angolense. Phytotherapy 61:91-92.

O desola I. F and O woseni T. A (2010): Development of Local Technology for a SmallScale Biochar Production Processes from Agricultural Wastes. Jaumal of Emerging Trends in EngineeingandAppliedSäeres(JETEAS) 1(2): 205208. 
Plaster, E. J. 1996. Sail Säeneand Management. 3rd ed. Albany: Delmar Publishers, Pp. 127

Spokas, K. A., Koskinen, W. C., Baker, J. M., and Reicosky, D. C., (2009): Impacts of woodchip biochar additions on greenhouse gas production and sorption/ degradation of twoherbicides in a Minnesota soil, Chemosphere 77, 574-575. Teehndogy. Earthscan, London and Sterling, VA. 416 pp.6

Tryon, J. (1999): Influence of fly ash on Soil Microbial activity and Growth. Journal of Envirament Qual Australian Pp.19.

Yao, F.X.; Arbestain, M.C.; Virgel, S.; Blanco, F.; Arostegui, J:; Maciá-Agulló, J.A.; and Macías, F (2010): Simulated geochemical weathering of a mineral ash-rich biochar in a modified soxhlet reactor. Chemosphere, 80, 724-732.
Yuan, J., R. Xu and H. Zhang, (2011): The forms of alkalis in the biochar produced from crop residues at different temperatures. Bioreserch Tehmology, 102: 3488-3489.

Zhao L., Cao X., Mašek O., and Zimmerman A., (2013): Heterogeneity of biochar properties as a function of feedstock sources and production temperatures. Jaumal of Hazardas Mateials, 256257, 1-9. 